\title{
Rhodamine B removal with activated carbons obtained from lignocellulosic waste
}

Viviane da Silva Lacerda ${ }^{1}$, Juan B. López-Sotelo ${ }^{1}$, Adriana Correa-Guimarães ${ }^{1}$, Salvador Hernández-Navarro ${ }^{1}$, Mercedes Sánchez-Báscones ${ }^{1}$, Luis M. Navas-Gracia ${ }^{1}$, Pablo MartínRamos $^{2}$ and Jesús Martín-Gil ${ }^{1 *}$

${ }^{1}$ Department of Agricultural and Forestry Engineering, ETSIIAA, Universidad de Valladolid, Avenida de Madrid 44, 34004 Palencia, Spain.

2 Department of Agricultural and Environmental Sciences, Higher Polytechnic School of Huesca, Universidad de Zaragoza, Carretera de Cuarte s/n, 22071, Huesca, Spain.

* E-mail: jesusmartingil@gmail.com; Tel.: +34 (979) 108347

\begin{abstract}
By-products from the wax production process from carnauba palm (leaves), from the extraction of oil from macauba seeds (endocarp) and from pine nut production (shell) have been assessed for activated carbon production, using $\mathrm{H}_{3} \mathrm{PO}_{4}$ or $\mathrm{CaCl}_{2}$ for their chemical activation. The resulting activated charcoals have been thoroughly characterized by elemental and thermal analysis, X-ray diffraction, infrared spectroscopy, electron scanning microscopy and $\mathrm{N}_{2}$ adsorption behavior. Subsequently, their adsorption capacity for the removal of rhodamine B $(\mathrm{RhB})$ from aqueous solutions has been evaluated by studying different parameters: contact time, $\mathrm{pH}$, adsorbent dose, initial dye concentration and solution temperature. The adsorption of RhB followed Freundlich's model in all cases. Kinetic studies indicate that the pseudo-second order model can be used for describing the dynamics of the adsorption process. Thermodynamic parameters have also been evaluated, indicating its endothermic and spontaneous nature. Finally, a preliminary analysis of the impact of cellulose content in the carbon precursor materials has been conducted, by using a mixture of native cellulose with one of the lignocellulosic materials.
\end{abstract}

Keywords: Acrocomia aculeata; activated carbon; adsorption; Copernicia prunifera; Pinus pinea; rhodamine $\mathrm{B}$.

\section{INTRODUCTION}

Synthetic dyes are widely used in industries, producing a large amount of toxic, carcinogenic, mutagenic, bio-accumulative wastewaters that pollute the environment (Chen et al., 2010) and which have been deemed as one of the most important groups of contaminants for the aquatic environment (Hosseini et al., 2011). Dyes are difficult to remove by conventional wastewater purification treatments due to their high stability against light, temperature, chemical and microbial attacks (Forgacs et al., 2004). Wastewater from industries also are contaminated by heavy metals (Lo et al., 2012), causing severe poisoning due to their high solubility in water and their non-biodegradability (Zaini et al., 2010). One of the most widely used products for the removal of these pollutants are activated carbons (activated charcoals), which can be produced from agricultural residues such as pecan nut shell (Bansode et al., 2004; Klasson et al., 2009; Ng et al., 2003), leather waste (Kong et al., 2013), olive-waste cake (Baccar et al., 2009), grass clippings, horse manure (Hao et al., 2013), rice husk waste (de Luna et al., 2013), etc.

The adsorption technique is used for the treatment of industrial effluents, and activated carbon is widely used for the removal of many pollutants, but it has the disadvantage of having a high associated cost. Consequently, other low-cost materials have been proposed as alternatives, in particular residual biomass, which is a natural biodegradable renewable product, with a 
minimum associated cost and which also has good adsorption properties for contaminants, either metals or chemical compounds (Paraskeva et al., 2008).

The adsorption involves the separation of a substance, followed by its accumulation or concentration on the surface of another material (Metcalf and Eddy, 2003). Activated charcoal of plant origin is a versatile adsorbent of great economic interest for the treatment of water, either for human consumption or for industrial purposes.

The aim of this research has been to find an efficient way to produce, characterize and use activated charcoals obtained from three little exploited lignocellulosic waste materials (from Copernicia prunifera, Acrocomia aculeata and Pinus pinea) for the adsorption of contaminants in wastewaters, taking Rhodamine- $\mathrm{B}(\mathrm{RhB})$ as a representative -and particularly harmfulexample of industrial pollutant dye. The effect of impregnation of the raw materials with $\mathrm{H}_{3} \mathrm{PO}_{4}$ and $\mathrm{CaCl}_{2}$ has been assessed, together with the impact of variations of the $\mathrm{pH}$, concentration of adsorbate, contact time, temperature and adsorbent dose on the efficiency of the adsorption process. Rhodamine-B adsorption mechanisms have been analyzed through isotherms, kinetic and thermodynamic studies. Moreover, the effect of the cellulose content in the precursor materials on the RhB removal capability of the resulting activated charcoals has been evaluated by its artificial increase with native cellulose for the first time.

\section{MATERIALS AND METHODS}

\subsection{Precursor materials}

Carnauba palm (Copernicia prunifera) leaves from Ceara (Brazil), macauba palm (Acrocomia aculeata) endocarp from Minas Gerais (Brazil) and stone pine (Pinus pinea) nut shells from Valladolid (Spain) have been selected as precursor lignocellulosic materials (da Silva Lacerda et al., 2015). Commercial native cellulose was supplied by Merck. Phosphoric acid $\left(\mathrm{H}_{3} \mathrm{PO}_{4}, 85 \%\right)$ and hydrochloric acid $(\mathrm{HCl}, 37 \%)$ were purchased from Panreac, and calcium chloride $\left(\mathrm{CaCl}_{2}\right.$, anhydrous, $\left.>93 \%\right)$ from Sigma Aldrich.

\subsection{Activated carbon preparation}

The chemical activation of the lignocellulosic raw materials was carried out using phosphoric acid and calcium chloride. Prior to the impregnation of the materials, they were washed with deionized water until constant $\mathrm{pH}$ and then were grounded on a Retsch ZM-100 ultra centrifugal mill to a particle size $<0.25 \mathrm{~mm}$. Subsequently, the materials were impregnated with solutions of phosphoric acid $(1 \mathrm{M})$ and calcium chloride $(1 \mathrm{M})$, using $8 \mathrm{~g}$ of each lignocellulosic product in 100 $\mathrm{mL}$ of the respective solutions $\left(\mathrm{H}_{3} \mathrm{PO}_{4}-1 \mathrm{M}\right.$ and $\left.\mathrm{CaCl}_{2}-1 \mathrm{M}\right)$ for $24 \mathrm{~h}$. After impregnation, the samples were filtered and dried at room temperature for $24 \mathrm{~h}$. The carbonization of the materials was conducted in a Mufla Digital oven mod. $10-\mathrm{PR} / 300$ at $500{ }^{\circ} \mathrm{C}$ for $1 \mathrm{~h}$ under $\mathrm{N}_{2}$ atmosphere. The materials resulting from carbonization were washed with $50 \mathrm{~mL}$ of hydrochloric acid (1M) for $1 \mathrm{~h}$ and sonicated for 10 minutes in a JP Selecta ultrasonic cleaning bath, and then filtered and washed with deionized water until chlorides complete elimination and constant $\mathrm{pH}$ were attained. The charcoals were finally dried to remove all moisture. Aforementioned washing process is essential in order to remove the chemical activating agents, allowing higher porosity (Peláez-Cid and Teutli-León, 2012).

\subsection{Physico-chemical characteristics of the activated carbons}

The behavior of the impregnated materials against pyrolysis was studied in a Mettler Toledo TGA/SDTA851e/SF/1100 thermal analyzer, by heating the samples from 25 to $830{ }^{\circ} \mathrm{C}$ at a 25 ${ }^{\circ} \mathrm{C} / \mathrm{min}$ rate under nitrogen atmosphere. The sample weights were in the 9.5 to $10.5 \mathrm{mg}$ range, each of them determined with $0.01 \mathrm{mg}$ precision.

$\mathrm{C}, \mathrm{H}$ and $\mathrm{N}$ contents were measured using a Leco CHN-600 Elemental Analyzer. Since ash and metal contents are low for these lignocellulosic materials, the oxygen content was calculated by subtraction, following a procedure analogous to that of Pastor-Villegas et al. (2006). 
The content of cellulose, hemicellulose and lignin was determined for each of the precursor materials as follows: the insoluble lignin content was calculated according to ANSI/ASTM standard (ANASI and ASTM, 1977) and holocellulose (hemicellulose+cellulose) was obtained after delignification of the sample and its content was determined using the technique described by Browning (1967). Cellulose content was determined according to ANSI/ASTM procedure (ANSI and ASTM, 1977) and hemicellulose content was then calculated by subtraction of cellulose content to that of holocellulose.

Structural characterization of the charcoals by X-ray powder diffraction was carried out in a Bruker D8 Advance Bragg-Brentano diffractometer, in reflection geometry. The diffractograms were recorded with $2 \theta$ sweep angles in the $5-70^{\circ}$ range at $0.02(2 \theta / \mathrm{sec})$ speed with $2 \mathrm{sec}$. exposure time.

The functional groups present on the surface were determined by infrared spectroscopy using a Thermo Nicolet 380 FT-IR apparatus equipped with a Smart Orbit Diamond ATR system.

The pore structure of the samples was characterized by nitrogen adsorption-desorption at 77 $\mathrm{K}$ using a Micromeritics ASAP 2020 surface area and porosity analyzer. Prior to the analysis, samples were degassed for 2 hours under vacuum at $393 \mathrm{~K}$.

The surface morphology was studied by scanning electron microscopy (SEM) in a FEI Quanta 200F apparatus.

\subsection{RhB adsorption assays}

Batch adsorption experiments were conducted to investigate the adsorption of Rhodamine B in the various activated carbons. All determinations were performed in triplicate biological replications, and the reported values correspond to the average.

To analyze the effect of $\mathrm{pH}$ on $\mathrm{RhB}$ adsorption, experiments were carried out at initial $\mathrm{pH}$ values ranging from 2 to 10 . The initial $\mathrm{pH}$ was controlled by the addition of dilute $\mathrm{HCl}$ or $\mathrm{NaOH}$ solutions. The effect of the dose of adsorbent was studied by varying the amount of carbon in the solution (from 2 to $8 \mathrm{~g} / \mathrm{L}$ ). The influence of contact time was assessed by using the same dye concentration and changing the contact time from 5 to $240 \mathrm{~min}$. The impact of the initial dye concentration was determined by isotherms at 25,35 and $45{ }^{\circ} \mathrm{C}$, varying the initial dye concentrations from 65 to $140 \mathrm{mg} / \mathrm{L}$ while keeping the dose of adsorbent and the contact time fixed. Finally, with a view to determining to what extent the amount of cellulose in the precursor materials affected the $\mathrm{RhB}$ adsorption capacity, a preliminary study has been conducted by mixing different amounts of native cellulose ( 0 wt.\%, 20 wt.\% and 50 wt.\%) with one of the lignocellulosic materials (pine nut shell) and comparing the percentage of removal of $\mathrm{RhB}$ for each the resulting activated charcoals. The aim of adding such native cellulose was to artificially increase the cellulose content prior to the activation phase (with $\mathrm{H}_{3} \mathrm{PO}_{4}$ ).

Rhodamine $\mathrm{B}$ concentrations in the solution before and after adsorption were determined with a Hitachi U-2001 UV-vis spectrophotometer at $552 \mathrm{~nm}$. The amount adsorbed per unit mass of biosorbent $(\mathrm{mg} / \mathrm{g})$ is calculated using the following equation (Eq. 1):

$$
q_{t}=\left[V\left(C_{0}-C_{t}\right)\right] / m
$$

where $C_{0}(\mathrm{mg} / \mathrm{L})$ is the initial concentration, $C_{\mathrm{t}}(\mathrm{mg} / \mathrm{L})$ is the concentration in the liquid phase at time $t, V(\mathrm{~L})$ the volume of the solution and $m(\mathrm{~g})$ the mass of adsorbent. In equilibrium conditions, $q_{\mathrm{t}}=q_{\mathrm{e}}$ and $C_{\mathrm{t}}=C_{\mathrm{e}}$.

\section{RESULTS AND DISCUSSION}

\subsection{Activated carbon characterization}

The $\mathrm{C}, \mathrm{H}, \mathrm{O}$ and $\mathrm{N}$ content (\% dry matter) of the precursor materials and their corresponding activated charcoals are summarized in Table S1. As expected, the carbon content is increased by carbonization (e.g., for carnauba leaves, it increases from $45.40 \%$ to $72.03 \%$ when impregnated with $\mathrm{CaCl}_{2}$ or to $67.61 \%$ when impregnated with $\left.\mathrm{H}_{3} \mathrm{PO}_{4}\right)$. The low nitrogen content for macauba endocarp $(0.03 \%)$ and pine nut shell $(0.03 \%)$ ensures low $\mathrm{NO}_{\mathrm{x}}$ emissions during the activated 
carbons preparation, while higher emissions can be expected for carnauba leaves $(3.40 \%)$. The highest oxygen content in the precursor materials corresponds to carnauba leaves $(48.7 \%)$, followed by pine nut shell (45.4\%) and macauba endocarp (41.2\%). These values are similar to those of other precursor materials or hardwoods such as those of white oak $(42 \%)$ or yellow poplar (47.3\%) (Jagtoyen and Derbyshire, 1998). It is worth noting that during the carbonization process, oxygen is consumed and this reduces its content in the carbonized materials to values between $17.94 \%$ and $26.93 \%$.

The cellulose, hemicellulose and lignin contents are summarized in Table S2. The highest cellulose content corresponds to carnauba leaves (37.5\%), followed by pine nut shell (30.9\%) and macauba endocarp (29.7\%).

For all the charcoals under study, the X-ray powder diffraction patterns (Figure S2) show the presence of broad peaks, indicating that most of the samples are amorphous, which is a typical characteristic of porous adsorbents (Bouchelta et al., 2008). However, some peaks arise sporadically in the profile for the activated carbon obtained from carnauba leaves treated with $\mathrm{H}_{3} \mathrm{PO}_{4}\left(\mathrm{C}_{-}\right.$carnauba_ $\left.\mathrm{H}_{3} \mathrm{PO}_{4}\right)$ and to a lesser extent in that the carbons obtained from carnauba leaves treated with $\mathrm{CaCl}_{2}\left(\mathrm{C}_{-}\right.$carnauba_ $\left.\mathrm{CaCl}_{2}\right)$ and from pine nut shell treated with $\mathrm{H}_{3} \mathrm{PO}_{4}$ (C_pine_nut_shell_ $\mathrm{H}_{3} \mathrm{PO}_{4}$ ), indicating the presence of a small fraction of crystalline material.

The chemical structure and functional groups of the prepared activated carbons have been studied by ATR-FTIR spectroscopy (Figure S3). The spectra can be interpreted on the basis of the characteristic vibration frequencies of the most common functional groups and structural components. The band at $2356 \mathrm{~cm}^{-1}$, present in the coal derivatives obtained from macauba (for both impregnations), can be assigned to carbon-oxygen groups due to the presence of the ketone group or to $\mathrm{CO}_{2}$ contamination. The band at around $1600 \mathrm{~cm}^{-1}$, present in all the activated carbons, can be attributed to aromatic rings or to $\mathrm{C}=\mathrm{C}$ bonds and involves the presence of carbonyl groups and the aromatization of the precursor (Guo and Rockstraw, 2007). All charcoals also exhibit wide bands in the $1000-1300 \mathrm{~cm}^{-1}$ range, with a maximum at $1160 \mathrm{~cm}^{-1}$, due to absorption caused by oxidized carbons and to the presence of $\mathrm{C}-\mathrm{O}$ stretching vibrations in acids, alcohols, phenols, ethers and esters (Freeman and Gimblett, 1988). Although this band was observed in all the spectra, it is more intense in the $\mathrm{H}_{3} \mathrm{PO}_{4}$ impregnated materials, because it is also characteristic of phosphorus and carbon-phosphorous compounds (Freeman et al., 1988), with the presence of hydrogen bonded P-O groups (Phan et al., 2006; Santhi et al., 2014) of phosphates or polyphosphates, the stretching vibrations of C-O bonds in (aromatic) P-O-C groups (Santhi et al., 2014 ) and in $\mathrm{O}=\mathrm{P}-\mathrm{OH}$ groups. For all impregnated carbons $\mathrm{H}_{3} \mathrm{PO}_{4}$ a shoulder can also be observed at $985 \mathrm{~cm}^{-1}$, characteristic of the phosphate group, which is also associated with asymmetric stretching vibrations of C-O-P groups for pentavalent phosphorus (Brasquet et al., 2000). The peak at ca. $760 \mathrm{~cm}^{-1}$ corresponds to $\mathrm{C}-\mathrm{Cl}$ vibrations, for carbons activated with $\mathrm{CaCl}_{2}$, and the band at $680 \mathrm{~cm}^{-1}$ can be ascribed to $\mathrm{C}=\mathrm{O}$ asymmetric vibration (Phan et al., 2006).

According to the shape of the nitrogen adsorption-desorption isotherms (Figure S4), they can be identified as type IV with hysteresis cycles, in accordance with the IUPAC classification (Sing, 1985). Type IV isotherms are typical of mesoporous solids (Zhou et al., 2009), where adsorption occurs in multilayers. This process is reflected in the central area of the upward isotherm as more layers on the solid surface are absorbed. Another property of type IV isotherms is the possibility of developing hysteresis loops, i.e., the adsorption and desorption curves do not match. Depending on the hysteresis curve type, in accordance with IUPAC, all our carbons exhibit a type $\mathrm{H} 4$ hysteresis, which is typical of complex materials containing both micropores and mesopores, such as activated carbons. Figure S5 shows the pore size distribution according to the Barrett-JoynerHalenda (BJH) (Barrett et al., 1951) method. The highest concentration of pores occurs in the 2050 Å range, confirming the presence of micropores and mesopores.

The textural parameters for the carbonaceous materials are summarized in Table 1. The materials impregnated with $\mathrm{H}_{3} \mathrm{PO}_{4}$ have higher Brunauer-Emmett-Teller (BET) surface for macauba endocarp $\left(371.12 \mathrm{~m}^{2} / \mathrm{g}\right)$ and pine nut shell $\left(296.01 \mathrm{~m}^{2} / \mathrm{g}\right)$, whereas in the case of carnauba leaves the BET is higher for the carbon impregnated with $\mathrm{CaCl}_{2}\left(402.43 \mathrm{~m}^{2} / \mathrm{g}\right)$. Pore volumes 
range from 0.12 to $0.24 \mathrm{~cm}^{3} / \mathrm{g}$, and the highest value corresponds again to C_carnauba_ $\mathrm{CaCl}_{2}$. The textural parameters for the activated carbons under study are within the ranges reported by other authors for different lignocellulosic residues, with surfaces areas ranging from 228 to 2410 $\mathrm{m}^{2} / \mathrm{g}$ and pore volumes in the 0.033 to $1.4 \mathrm{~cm}^{3} / \mathrm{g}$ range (Ioannidou and Zabaniotou, 2007; Zuo et al., 2009). It is worth noting that $\mathrm{CaCl}_{2}$ activated carbons have larger average pore sizes (18.25$23.16 \AA$ ) in comparison with those activated with $\mathrm{H}_{3} \mathrm{PO}_{4}(17.26-19.97 \AA)$, so it can be inferred that $\mathrm{CaCl}_{2}$ activation produces larger pores.

Table 1. Textural parameters for the carbonaceous materials and their precursors, obtained from the $\mathrm{N}_{2}$ adsorption isotherm using standard conditions at $77 \mathrm{~K}$

\begin{tabular}{ccccc}
\hline Materials & $\begin{array}{c}\text { BET surface } \\
\text { area }\left(\mathrm{m}^{2} / \mathrm{g}\right)\end{array}$ & $\begin{array}{c}\text { Pore volume } \\
\left(\mathrm{cm}^{3} / \mathrm{g}\right)\end{array}$ & $\begin{array}{c}\text { Micropore volume } \\
\left(\mathrm{cm}^{3} / \mathrm{g}\right)\end{array}$ & $\begin{array}{c}\text { Pore size } \\
(\AA)\end{array}$ \\
\hline Carnauba leaves & 0.8581 & 0.000359 & 0.000359 & 21.246 \\
Macauba endocarp & 0.6028 & 0.002019 & -0.000111 & 133.99 \\
Pine nut shell & 0.8608 & 0.00316 & -0.000163 & 146.97 \\
C_carnauba_CaCl & 430.695 & 0.249375 & 0.121191 & 23.160 \\
C_carnauba_H $\mathrm{HOO}_{4}$ & 402.430 & 0.200946 & 0.123078 & 19.973 \\
C_macauba_CaCl & 265.493 & 0.121151 & 0.082070 & 18.252 \\
C_macauba_H $\mathrm{HO}_{2}$ & 371.126 & 0.160181 & 0.126290 & 17.264 \\
C_pine_nut_shell_CaCl & 290.053 & 0.136993 & 0.082738 & 18.892 \\
C_pine_nut_shell_H $\mathrm{H}_{3} \mathrm{PO}_{4}$ & 296.017 & 0.132521 & 0.100583 & 17.907 \\
\hline
\end{tabular}

The surfaces of all the raw materials and active charcoals have been analyzed by scanning electron microscopy (see Figure S6). Although the micropores and mesopores are not visible, the micrographs allow to observe the shape and location of macropores on the surface of the materials. By combining the pore size distribution obtained from nitrogen adsorption and the SEM micrographs, it is possible to obtain complete information on pores development during carbonization and activation. In the precursor materials no macropores are observed in the SEM micrographs. With regard to the activated carbons obtained from carnauba leaves, macropores are found primarily within the fiber, in analogy with those reported for the activation of different fibers by other authors (Brasquet et al., 2000; Phan et al., 2006). In the case of the carbons derived from macauba endocarp and pine nut shell, macropores appear distributed all throughout the material surface. The macropores for $\mathrm{CaCl}_{2}$ activated carbons show more variability and are larger than those of the materials activated with $\mathrm{H}_{3} \mathrm{PO}_{4}$. The distribution and shape of the pores in the activated carbons significantly vary depending on the raw materials used.

\subsection{Effect of pH on RhB adsorption capacity}

The $\mathrm{pH}$ of the solution can either promote or prevent the dye adsorption, since it can affect the surface charge of the adsorbent and the adsorbate species in solution (Lin et al., 2013). Figure 1 depicts the effect of the $\mathrm{pH}$ of the solution on $\mathrm{RhB}$ adsorption on the activated charcoals under study in the 2-10 pH range. As the $\mathrm{pH}$ increases from 2 to 8 , a slight increase on the $\mathrm{RhB}$ adsorption capacity can be observed (confirmed by a one-way ANOVA), which is more pronounced for those carbons activated with $\mathrm{H}_{3} \mathrm{PO}_{4}$. At low $\mathrm{pH}$ values, the high concentration of $\mathrm{H}^{+}$ions promotes the protonation of the functional groups of the adsorbent, charging it more positively and leading to repulsion of the cationic dye molecules. Moreover, at low $\mathrm{pH}$ values, the $\mathrm{H}^{+}$ions compete with $\mathrm{RhB}$ molecules for the adsorption sites. On the other hand, when the $\mathrm{pH}$ of the solution is increased, the surface of the carbons gets negatively charged due to $\mathrm{OH}^{-}$ adsorption and deprotonation of functional groups, thus improving the adsorption by electrostatic attraction (Ahmad and Kumar, 2010). The decrease in the absorbance when the $\mathrm{pH}$ is higher than 8 is due to the formation of hydrated ions of $\mathrm{RhB}$, which lead to a larger molecular structure (dimer) that hinders the entry of the dye into the pores of the material. This same behavior-with an increase in the absorption capacity and a subsequent decrease as the $\mathrm{pH}$ is increased- has also been reported in a study of $\mathrm{RhB}$ removal by activated carbon produced from Acacia nilotica leaves with $\mathrm{H}_{2} \mathrm{SO}_{4}$ (Santhi et al. (2014). Talebnia et al. (2010) also reported an optimal pH around 
7 for the adsorption of $\mathrm{RhB}$ on montmorillonite $\left((\mathrm{Na}, \mathrm{Ca})_{0.33}(\mathrm{Al}, \mathrm{Mg})_{2}\left(\mathrm{Si}_{4} \mathrm{O}_{10}\right)(\mathrm{OH})_{2} \cdot n \mathrm{H}_{2} \mathrm{O}\right)$. The highest adsorption capacity the activated charcoals presented herein occurs at $\mathrm{pH} 8$. Since the work system is designed to operate in natural waters at $\mathrm{pH}$ in the 6-8 interval, no $\mathrm{pH}$ adjustment was required for the tests on the effect of adsorbent dose discussed in next section.

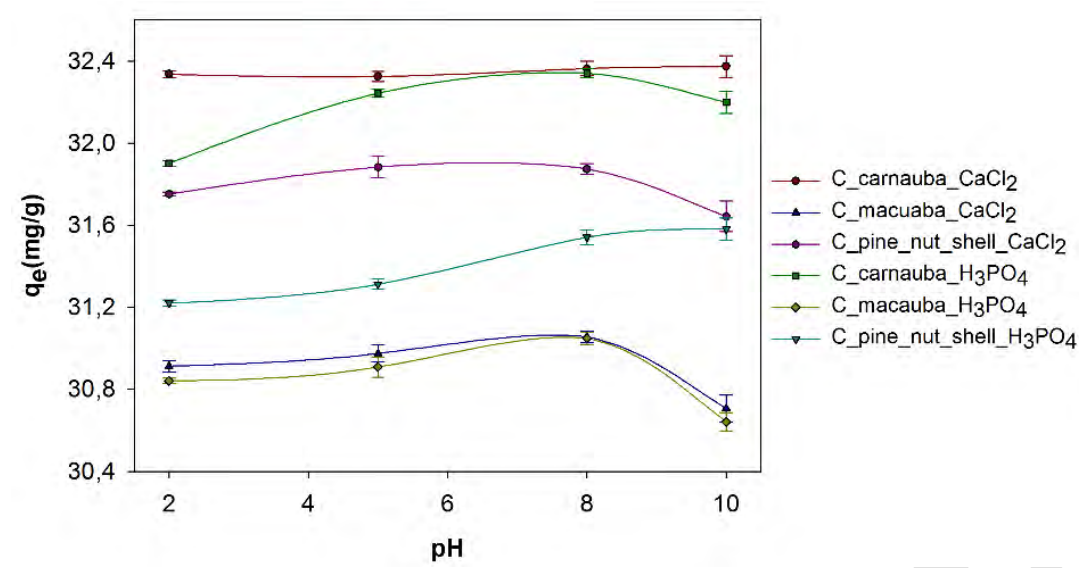

Figure 1. Effect of the $\mathrm{pH}$ of the solution on $\mathrm{RhB}$ adsorption (adsorbent dose $=2 \mathrm{~g} / \mathrm{L}$; temperature $=25^{\circ} \mathrm{C}$, $[\mathrm{RhB}]_{0}=65 \mathrm{mg} / \mathrm{L}$; contact time $=120 \mathrm{~min}$ )

\subsection{Effect of activated carbon dosage on adsorption}

Figure 2 shows the percentage of $\mathrm{RhB}$ removal as a function of the dose of activated charcoal. As expected, for all the activated carbon atoms under study, dye adsorption increased with increasing carbon concentration (e.g., from $87.6 \%$ to $99.85 \%$ for $\mathrm{C}$ carnauba_ $\mathrm{CaCl}_{2}$ ). This increase in the removal percentage can be attributed to the increase in the available surface area and availability of more adsorption sites (Garg et al., 2004). On the basis of the results presented in Figure 2, it can inferred that the most efficient activated charcoal dose is $4 \mathrm{~g} / \mathrm{L}$, since further increase in dose $(6$ or $8 \mathrm{~g} / \mathrm{L})$ does not lead to a significant increase in the removal of the dye. This can be attributed to overlapping or aggregation of adsorption sites, resulting in decrease in total adsorbent surface area available to the pollutant and an increase in diffusion path length (Garg et al., 2004). The same behavior has also been reported by other authors, in relation to the absorption of RhB (Namasivayam et al., 2001) and to the adsorption of other dyes (Wang et al., 2010).

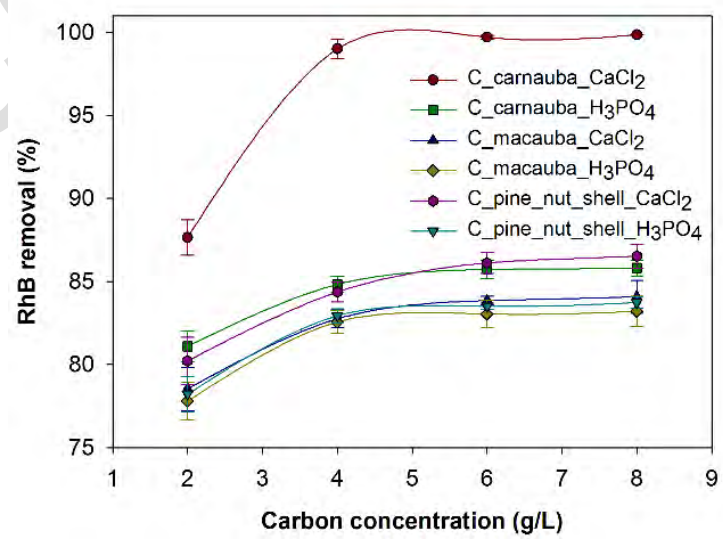

Figure 2. Effect of activated carbon dosage on $\mathrm{RhB}$ removal $\left([\mathrm{Rh}-\mathrm{B}]_{0}=80 \mathrm{mg} / \mathrm{L}\right.$, contact time $=120 \mathrm{~min}$; $\mathrm{pH}=7$; temperature $=25^{\circ} \mathrm{C}$ ).

\subsection{Impact of contact time on $\mathrm{RhB}$ removal}


As it can be observed from Figure 3, the adsorption is very rapid at first and it gradually decreases till equilibrium is reached after $120 \mathrm{~min}$, for all the activated carbons under study. In general, it can be assumed that the dyes removal mechanism, by adsorption, consists of the following steps (Lazaridis and Asouhidou, 2003): (i) diffusion across the fluid phase surrounding the adsorbent particles, i.e., external diffusion or film diffusion; (ii) diffusion in the liquid contained in the pores and/or along the pore walls, which is so-called internal diffusion or intraparticle diffusion; and (iii) adsorption and desorption between the adsorbate and active sites, i.e., mass action. The decrease in the amount of dye adsorption versus time may be due to aggregation processes of the dye molecules. This aggregation can prevent migration of the adsorbate, saturate the adsorption sites and generate a resistance to diffusion of dye molecules. Other authors have also reported a similar behavior in the absorption of $\mathrm{RhB}$, with a rapid initial phase followed by a gradually slower one (Fernandez et al., 2014; Gad and El-Sayed, 2009; Wang and Zhu, 2007).
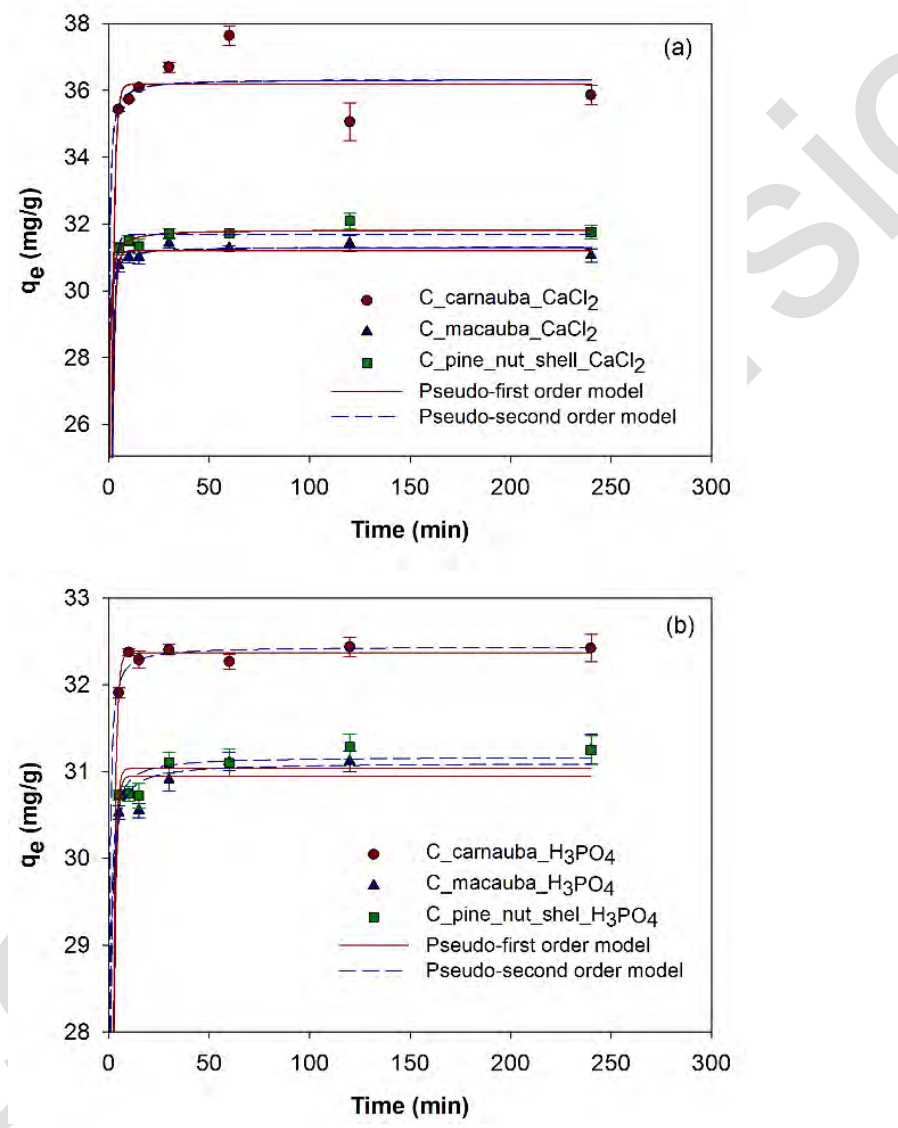

Figure 3. Effect of contact time on RhB adsorption for the different carbons activated with (a) $\mathrm{CaCl}_{2}$ and (b) $\mathrm{H}_{3} \mathrm{PO}_{4}\left(\mathrm{pH}=7\right.$; temperature $=25{ }^{\circ} \mathrm{C},[\mathrm{RhB}]_{0}=80 \mathrm{mg} / \mathrm{L}$; absorbent dose $\left.=2 \mathrm{~g} / \mathrm{L}\right)$. Fitting of the data conducted by kinetic models.

\subsection{Effect of dye initial concentration and solution temperature}

Figure 4 depicts the effect of varying the initial $\mathrm{RhB}$ concentration on the adsorption for the different activated carbons at 25,35 and $45^{\circ} \mathrm{C}$. An increase in the adsorption capacity with increasing dye concentration is observed. The largest increase occurs for $\mathrm{C}_{-}$carnauba_ $\mathrm{CaCl}_{2}$, for which it changes from 32.61 to $42.10 \mathrm{mg} / \mathrm{L}$. This increase in adsorption capacity is probably due to the increase in the driving force of the concentration gradient, which decreases resistance to the mass transfer of ions between the aqueous medium and the sorbent (Aksu and Dönmez, 2003). This behavior has been widely reported in the literature (Gad and El-Sayed, 2009; Kadirvelu et al., 2005; Santhi et al., 2014). 

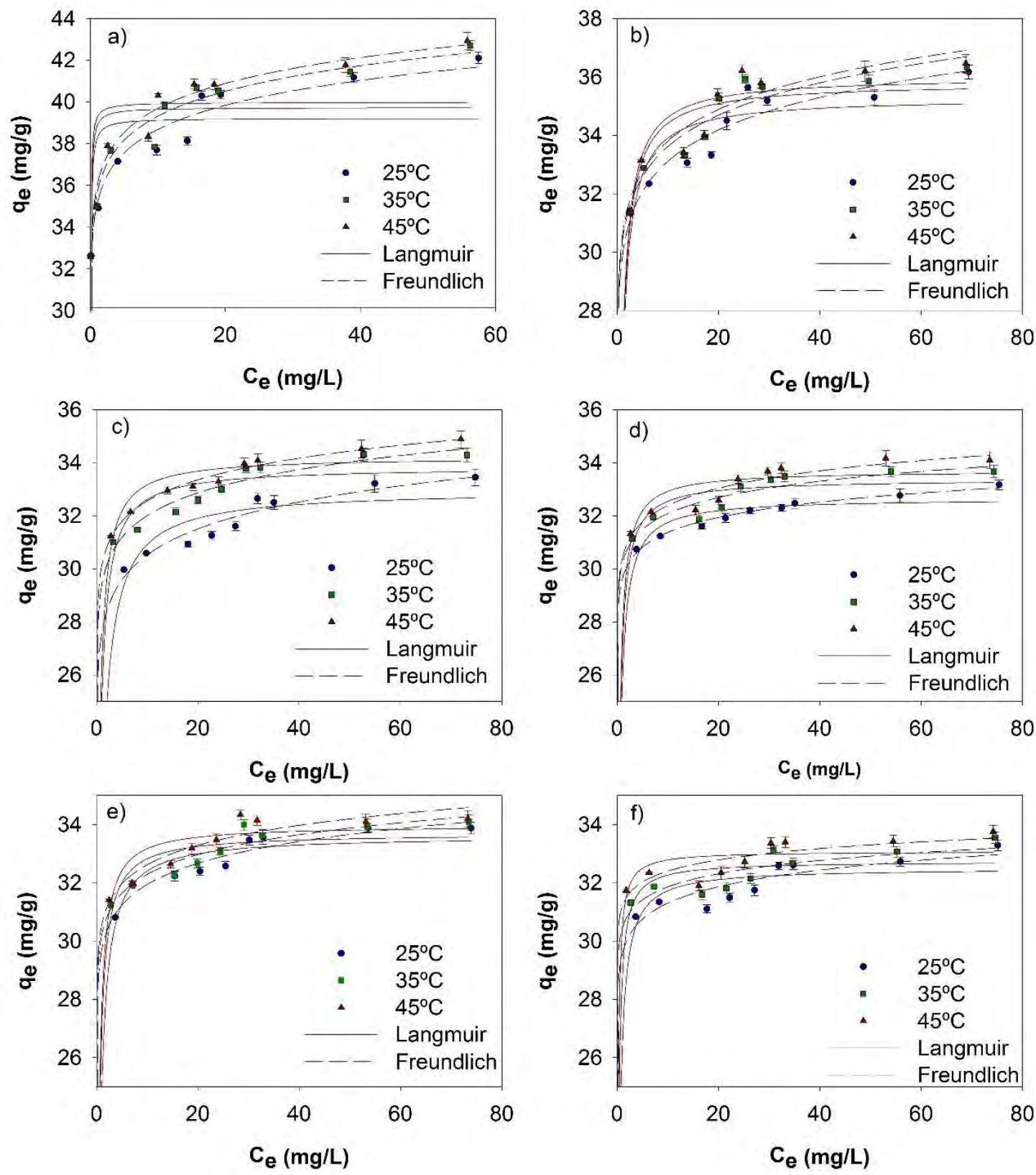

Figure 4. Effect of $\mathrm{RhB}$ initial concentration on the adsorption by (a) $\mathrm{C}$-carnauba_ $\mathrm{CaCl}_{2} ;(b)$

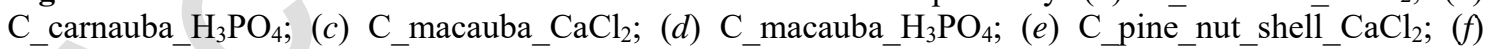
C_pine_nut_shell_ $\mathrm{H}_{3} \mathrm{PO}_{4}(\overline{\mathrm{pH}}=7$; adsorbent dose $=\overline{2} \mathrm{~g} / \mathrm{L}$; contact time $=120 \mathrm{~min})$ at three different temperatures $\left(25,35\right.$ and $\left.45^{\circ} \mathrm{C}\right)$. The data have been fitted according to Langmuir y Freundlich non-linear models.

Moreover, the increase in temperature also resulted in an in increase in the adsorption capacity for all active carbons. Amongst the different materials under study, C macauba_ $\mathrm{CaCl}_{2}$ is the one with the most significant increase in the adsorption capacity, which changed from 33.44 $\mathrm{mg} / \mathrm{L}$ at $25{ }^{\circ} \mathrm{C}$ to $34.87 \mathrm{mg} / \mathrm{L}$ at $45^{\circ} \mathrm{C}$. This increase in adsorption capacity with temperature is due to the fact that the process is endothermic, leading to an increase in the intraparticle diffusion speed of the dye in the pores or to the formation of new adsorption sites (Karthikeyan et al., 2005). Wang and Zhu (2007) also reported the endothermic nature of the RhB adsorption process on a commercial activated carbon pretreated with acid.

\subsubsection{Kinetic study}


The experimental data have been fitted by nonlinear regression to the two most commonly used kinetic models in the literature: the model pseudo-first order and the pseudo-second order model, which are described below.

The pseudo-first order model (Lagergren, 1898) considers that the occupation rate of adsorption sites is proportional to the number of unoccupied sites (see Eq. 2). By integrating this equation under conditions $q=0$ at $t=0$ and $q=q_{\mathrm{t}}$ at $t=\mathrm{t}$, Eq. 3 is obtained, where $q_{\mathrm{t}}(\mathrm{mg} / \mathrm{g})$ is the absorption of the dye in the time $\mathrm{t}, q_{\mathrm{e}}(\mathrm{mg} / \mathrm{g})$ is the adsorption capacity in equilibrium, $t(\mathrm{~min})$ is the exposure time and $k_{1}\left(\mathrm{~h}^{-1}\right)$ is the adsorption rate constant:

$$
\begin{aligned}
& \frac{d q}{d t}=k_{1}\left(q_{e}-q\right) \\
& q_{t}=q_{e}\left(1-e^{-k_{1} t}\right)
\end{aligned}
$$

The pseudo-second order model (Ho, 1995) describes how the adsorption mechanism follows a second-order reaction. The absorption rate is then proportional to the square of the number of unoccupied sites (see Eq. 4). By integrating this equation under the following conditions, $q=0$ at $t=0$ and $q=q_{\mathrm{t}}$ at $t=\mathrm{t}$, Eq. 5 is obtained, where $k_{2}(\mathrm{~g} / \mathrm{mg} \cdot \mathrm{h})$ is the rate constant of the pseudo-second order adsorption equation:

$$
\begin{gathered}
\frac{d q}{d t}=k_{2}\left(q_{e}-q\right)^{2} \\
q_{t}=\frac{t}{1 / k_{2} q_{e}^{2}+t / q_{e}}
\end{gathered}
$$

The adsorption kinetic fittings are shown in Figure 3, and all the calculated kinetic parameters are summarized in Table 2. C_carnauba_ $\mathrm{H}_{3} \mathrm{PO}_{4}$ presents the fastest rate of dye removal $\left(k_{1}\right)$, followed by C_carnauba_CaCl $2>$ C_pine_nut_shell_CaCl $>$ C_macauba_ $\mathrm{CaCl}_{2}>$ C_pine_nut_shell_ $\mathrm{H}_{3} \mathrm{PO}_{4}>\mathrm{C}$ _macauba_H $\mathrm{H}_{3} \mathrm{PO}_{4}$. Although correlation coefficients higher than 0.99 were obtained for all activated carbons under study for the pseudo-first order model, the calculated adsorption capacities $\left(q_{\mathrm{e} \_ \text {cal }}\right)$ were significantly different from the experimental values $\left(q_{\mathrm{e} \_ \text {exp }}\right)$ (Table 2). A similar situation has been reported by Ahmad et al. (2012), who observed that for very quick adsorption processes the $r^{2}$ values were similar for both the pseudo-first and the pseudo-second order models, and then attention should be paid to $q_{\mathrm{e} \_ \text {cal }}$ values so as to distinguish

\begin{tabular}{|c|c|c|c|c|c|c|c|}
\hline \multirow[b]{2}{*}{ Samples } & \multirow[b]{2}{*}{$q_{\text {e_exp }}$} & \multicolumn{3}{|c|}{ Pseudo-first order model } & \multicolumn{3}{|c|}{ Pseudo-second order model } \\
\hline & & $\begin{array}{c}\boldsymbol{k}_{\mathbf{1}} \\
(\mathrm{min})\end{array}$ & $\begin{array}{c}\boldsymbol{q}_{\text {e_cal }} \\
\left(\mathrm{mg} \cdot \mathrm{g}^{-1}\right)\end{array}$ & $r^{2}$ & $\begin{array}{c}\mathbf{k}_{\mathbf{2}} \\
\left(\mathrm{g} \cdot \mathrm{mg}^{-1} \cdot \min ^{-1}\right)\end{array}$ & $\begin{array}{c}\boldsymbol{q}_{\mathrm{e} \text { _cal }} \\
\left(\mathrm{mg} \cdot \mathrm{g}^{-1}\right)\end{array}$ & $r^{2}$ \\
\hline C_carnauba_CaCl ${ }_{2}$ & 33.315 & 0.769 & 36.186 & 0.998 & 0.236 & 36.363 & 0.998 \\
\hline $\mathrm{C}^{-}$carnauba $\mathrm{H}_{3} \mathrm{PO}_{4}$ & 2.429 & 0.851 & 32.365 & 0.999 & 0.431 & 32.467 & 0.999 \\
\hline C_macauba_- $\mathrm{CaCl}_{2}$ & 31.371 & 0.850 & 31.197 & 0.999 & 0.350 & 31.347 & 0.999 \\
\hline C_macauba_- $\mathrm{H}_{3} \mathrm{PO}_{4}$ & 31.099 & 0.856 & 30.948 & 0.999 & 0.280 & 31.055 & 0.999 \\
\hline C_pine_nut_shell_ $\mathrm{CaCl}_{2}$ & 31.855 & 0.861 & 31.6 & 0.999 & 0.299 & 31.847 & 0.999 \\
\hline 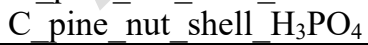 & 31.184 & 0.920 & 31.035 & 0.999 & 0.332 & 31.152 & 0.999 \\
\hline
\end{tabular}
which fitting is the most suitable. Consequently, it can be concluded that the fitting of the dye adsorption with a pseudo-first order is not good.

Table 2. Kinetic parameters for rhodamine B adsorption for the different activated carbons under study

On the other hand, when the pseudo-second order kinetic model is chosen, not only the correlation coefficients are higher than 0.99 (Table 2$)$, but the calculated adsorption values $\left(q_{\text {e_cal }}\right)$ are also in good agreement the experimental data $\left(q_{\mathrm{e}_{-} \text {exp }}\right)$. This better fitting to a pseudo-secondorder model suggests that the adsorption rate is more dependent on the availability of adsorption sites than on the dye concentration in the solution. Similar phenomena have been observed for $\mathrm{RhB}$ adsorption different biosorbents (Kadirvelu et al., 2005; Wang et al., 2010). 


\subsection{Adsorption isotherms}

The adsorption data for the different activated carbons have been fitted by non-linear Langmuir and Freundlich models. SigmaPlot ${ }^{\mathrm{TM}}$ v.10 (Systac Software Inc) software was used for these fittings.

The Langmuir model (Eq. 6) assumes that adsorption occurs in a monolayer, where the active sites are identical and energetically equivalent, that there are no interactions between the adsorbed molecules and that no transmigration of the molecules adsorbed takes place on the adsorption surface (Langmuir, 1918):

$$
q_{e}=\frac{k_{L} q_{\max } C_{e}}{1+k_{L} C_{e}}
$$

where $q_{\mathrm{e}}(\mathrm{mg} / \mathrm{g})$ is the adsorption capacity in equilibrium, $C_{\mathrm{e}}(\mathrm{mg} / \mathrm{L})$ is the pollutant concentration in equilibrium, $k_{\mathrm{L}}(\mathrm{L} / \mathrm{mg})$ is the Langmuir constant related to the assorption energy, which quantitatively reflects the affinity between the adsorbent and adsorbate, and $q_{\max }(\mathrm{mg} / \mathrm{g})$ is the theoretical maximum adsorption capacity.

The essential characteristics of the Langmuir adsorption isotherm can be expressed as a dimensionless constant, called separation factor or equilibrium parameter $\left(R_{\mathrm{L}}\right)$, which is defined by Eq. 7) (Hall et al., 1966):

$$
R_{L}=\frac{1}{1+k_{L} C_{0}}
$$

where $C_{0}$ is the initial dye concentration $(\mathrm{mg} / \mathrm{L})$. The $R_{\mathrm{L}}$ value indicates the shape of the isotherm, which can be irreversible $\left(R_{\mathrm{L}}=0\right)$, favorable $\left(0<R_{\mathrm{L}}<1\right)$, linear $\left(R_{\mathrm{L}}=1\right)$ or unfavorable $\left(R_{\mathrm{L}}>1\right)$.

Freundlich isotherm is an empirical equation (Eq. 8) which considers the possibility of multilayer adsorption in multiple layers with a heterogeneous energy distribution of the active sites, accompanied by interactions between the adsorbed molecules (Freundlich, 1906):

$$
q_{e}=k_{F} \cdot C_{e}^{1 / n}
$$

where $k_{\mathrm{F}}\left(\mathrm{mg} \cdot \mathrm{g}^{-1}\left(\mathrm{mg} \cdot \mathrm{L}^{-1}\right)^{1 / n}\right)$ is the Freundlich isotherm constant, which is an indicator of the adsorptive capacity of an adsorbent for a solute, and $n$ is a measure of the intensity of the adsorption or surface heterogeneity (a value closer to zero represents a more heterogeneous surface).

The fittings of the experimental data to the Langmuir and Freundlich isotherm models at different temperatures are depicted in Figure 4. The correlation coefficients $\left(r^{2}\right)$ and the constants obtained from the application of the Langmuir and Freundlich models are summarized in Table 3. In light of these data, Freundlich model has a better fit to the experimental data than Langmuir model in all cases. This reveals the heterogeneity of the surface of the activated carbons under study.

The $R_{\mathrm{L}}$ values (Table 3 ) confirm that the dye adsorption is favorable, with values below 1 for all the activated carbons. The maximum adsorption $\left(q_{\max }\right)$ for the different coals decrease in the following order: C_carnauba_CaCl $\mathrm{CaCl}_{2}>\mathrm{C}_{-}$carnauba_ $\mathrm{H}_{3} \mathrm{PO}_{4}>\mathrm{C}_{-}$macauba_ $\mathrm{CaCl}_{2}>$ C_pine_nut_shell_CaCl $2>$ C_pine_nut_shell_ $\mathrm{H}_{3} \mathrm{PO}_{4}>\mathrm{C}$-macauba_H $\mathrm{H}_{3} \mathrm{PO}_{4}$. All the charcoals activated with $\mathrm{CaCl}_{2}$ showed higher $q_{\max }$ values than those activated with $\mathrm{H}_{3} \mathrm{PO}_{4}$, as expected for the larger size of their pores (discussed above).

Table 3. Adsorption isotherm parameters for rhodamine B adsorption for the different activated carbons under study

\begin{tabular}{ccccccc}
\hline \multirow{2}{*}{ Sample } & \multirow{2}{*}{$\left({ }^{\circ} \mathrm{C}\right)$} & \multicolumn{5}{c}{ Langmuir constants } \\
\cline { 3 - 7 } & 25 & $\boldsymbol{q}_{\max }\left(\mathrm{mg} \cdot \mathrm{g}^{-1}\right)$ & $\boldsymbol{K}_{\mathbf{L}}\left(\mathrm{L} \cdot \mathrm{mg}^{-1}\right)$ & $\boldsymbol{r}^{2}$ & $\boldsymbol{R}_{\mathbf{L}}$ & $\boldsymbol{\sigma}$ \\
\hline \multirow{2}{*}{ C_carnauba_CaCl } & & 39.218 & 38.881 & 0.976 & $3.21 \mathrm{E}-07$ & 2.057 \\
& 35 & 39.732 & 43.164 & 0.975 & $2.90 \mathrm{E}-07$ & 2.093
\end{tabular}




\begin{tabular}{|c|c|c|c|c|c|c|}
\hline & 45 & 39.983 & 52.488 & 0.975 & 2.38E-07 & 2.159 \\
\hline \multirow{3}{*}{ C_carnauba_H ${ }_{3} \mathrm{PO}_{4}$} & 25 & 35.279 & 2.459 & 0.994 & $5.08 \mathrm{E}-06$ & 0.891 \\
\hline & 35 & 35.796 & 2.479 & 0.996 & $5.04 \mathrm{E}-06$ & 0.779 \\
\hline & 45 & 35.998 & 2.497 & 0.995 & $5.01 \mathrm{E}-06$ & 0.809 \\
\hline \multirow{3}{*}{ C_macauba_CaCl ${ }_{2}$} & 25 & 32.959 & 1.505 & 0.996 & $8.31 \mathrm{E}-06$ & 0.642 \\
\hline & 35 & 33.830 & 2.661 & 0.996 & 4.70E-06 & 0.671 \\
\hline & 45 & 34.217 & 3.123 & 0.998 & $4.00 \mathrm{E}-06$ & 0.530 \\
\hline \multirow{3}{*}{$\mathrm{C} \_$macauba_H $\mathrm{H}_{3} \mathrm{PO}_{4}$} & 25 & 32.651 & 3.492 & 0.998 & $3.58 \mathrm{E}-06$ & 0.365 \\
\hline & 35 & 33.363 & 3.973 & 0.998 & $3.15 \mathrm{E}-06$ & 0.522 \\
\hline & 45 & 33.694 & 4.241 & 0.997 & $2.95 \mathrm{E}-06$ & 0.568 \\
\hline \multirow{3}{*}{ C_pine_nut_shell_ $\mathrm{CaCl}_{2}$} & 25 & 33.606 & 2.688 & 0.998 & $4.65 \mathrm{E}-06$ & 0.462 \\
\hline & 35 & 33.685 & 3.795 & 0.997 & $3.29 \mathrm{E}-06$ & 0.553 \\
\hline & 45 & 33.971 & 4.131 & 0.998 & $3.03 \mathrm{E}-06$ & 0.555 \\
\hline \multirow{3}{*}{$\mathrm{C}$ _pine_nut_shell_ $\mathrm{H}_{3} \mathrm{PO}_{4}$} & 25 & 32.498 & 4.117 & 0.997 & $3.04 \mathrm{E}-06$ & 0.601 \\
\hline & 35 & 32.732 & 6.899 & 0.997 & $1.81 \mathrm{E}-06$ & 0.589 \\
\hline & 45 & 33.080 & 11.055 & 0.997 & $1.13 \mathrm{E}-06$ & 0.560 \\
\hline & & & & & & $P$ \\
\hline \multirow[b]{2}{*}{ Sample } & & \multicolumn{5}{|c|}{ Freundlich constants } \\
\hline & $\boldsymbol{T}\left({ }^{\circ} \mathrm{C}\right)$ & $\begin{array}{c}\boldsymbol{K}_{\boldsymbol{F}} \\
\left(\mathrm{mg} \cdot \mathrm{g}^{-1}\left(\mathrm{mg} \cdot \mathrm{L}^{-1}\right)^{1 / n}\right)\end{array}$ & $n$ & & & $\sigma$ \\
\hline \multirow{3}{*}{ C_carnauba_CaCl $\mathrm{Ca}_{2}$} & 25 & 35.062 & 23.463 & & .997 & 0.703 \\
\hline & 35 & 35.601 & 23.211 & & .997 & 0.635 \\
\hline & 45 & 35.953 & 23.285 & & .998 & 0.613 \\
\hline \multirow{3}{*}{ C_carnauba_ $\mathrm{H}_{3} \mathrm{PO}_{4}$} & 25 & 29.755 & 21.599 & & .998 & 0.539 \\
\hline & 35 & 30.267 & 21.989 & & .998 & 0.543 \\
\hline & 45 & 30.431 & 21.936 & & .997 & 0.607 \\
\hline \multirow{3}{*}{ C_macauba_CaCl ${ }_{2}$} & 25 & 27.459 & 21.832 & & .999 & 0.333 \\
\hline & 35 & 29.306 & 26.191 & & .999 & 0.325 \\
\hline & 45 & 30.039 & 28.644 & & .999 & 0.155 \\
\hline \multirow{3}{*}{$\mathrm{C} \_$macauba_H $\mathrm{H}_{3} \mathrm{PO}_{4}$} & 25 & 29.555 & 38.655 & & .999 & 0.094 \\
\hline & 35 & 30.141 & 36.983 & & .999 & 0.339 \\
\hline & 45 & 30.333 & 35.1259 & & .999 & 0.326 \\
\hline \multirow{3}{*}{ C_pine_nut_shell_ $\mathrm{CaCl}_{2}$} & 25 & 29.629 & 30.664 & & .999 & 0.288 \\
\hline & 35 & 30.147 & 33.536 & & .999 & 0.312 \\
\hline & 45 & 30.488 & 34.108 & & .999 & 0.359 \\
\hline \multirow{3}{*}{ C_pine_nut_shell_ $\mathrm{H}_{3} \mathrm{PO}_{4}$} & 25 & 29.506 & 38.957 & & .999 & 0.392 \\
\hline & 35 & 30.406 & 49.314 & & .999 & 0.408 \\
\hline & 45 & 31.1571 & 58.790 & & .999 & 0.393 \\
\hline
\end{tabular}

Table S3 summarizes a comparison of the absorption capacity for the activated charcoals presented herein with others found in the literature (for a more general comparison of other lignocellulosic products as adsorbents, the interested reader is referred to, for example, the work by Parab et al. (2009)). Since the activated carbons prepared from the selected lignocellulosic waste materials have adsorption capacities between 33.08 and $39.98 \mathrm{mg} / \mathrm{g}$, comparable to the values for commercial activated carbon (Bhadusha and Ananthabaskaran, 2012) and above the average of the values reported in the literature (which vary from 1.6 to $60.8 \mathrm{mg} / \mathrm{L}$ ). Nonetheless, it should be noted that an accurate comparison is not feasible in this case, given the differences on the nature of the precursors, on the activation agents and on the operational conditions amongst the different studies.

\subsection{Thermodynamic parameters}

The thermodynamic parameters for the adsorption process have been estimated from the Langmuir constants $(\mathrm{mmol} / \mathrm{g})$. The enthalpy change $\left(\Delta \mathrm{H}^{0}\right)$, the entropy change $\left(\Delta \mathrm{S}^{0}\right)$ and the change in Gibbs free energy $\left(\Delta \mathrm{G}^{0}\right)$ for the adsorption process can be calculated from the $k_{\mathrm{L}}$ constant and the temperature (T) using the following equations (Singh, 1988): 


$$
\begin{gathered}
\Delta G^{0}=-R T \cdot \ln K_{L} \\
\Delta G^{0}=\Delta H^{0}-T \cdot \Delta S^{0} \\
\ln K_{L}=\left(\Delta S^{0} / R T\right)+\left(\Delta H^{0} / R\right)
\end{gathered}
$$

where $R$ is the ideal gas constant $\left(8.314 \times 10^{-3} \mathrm{~kJ} / \mathrm{mol} \cdot \mathrm{K}\right), T$ is the temperature in Kelvin, and $K_{L}$ is the distribution coefficient.

The thermodynamic parameters are summarized in Table 4. It can be observed that all the activated carbons under study have negative $\Delta G^{0}$ values, so the processes are spontaneous in nature. It is also worth noting that $\Delta \mathrm{G}^{0}$ values become more negative with increasing temperature, which implies that the process is more spontaneous at higher temperatures. $\Delta \mathrm{H}^{0}$ was positive for all coals, indicating that the adsorption process is endothermic, and have values below $40 \mathrm{~kJ} \cdot \mathrm{mol}^{-}$ ${ }^{1}$, characteristic of a physical-type absorption (Bhatnagar et al., 2009). The maximum monolayer $\mathrm{RhB}$ adsorption capacity $\left(\mathrm{q}_{\max }\right)$ increases when the temperature is increased from 25 to $45{ }^{\circ} \mathrm{C}$, further confirming the endothermic nature of the process. The positive value of $\Delta \mathrm{S}^{0}$ suggests increased randomness at the solid/solution interface during the adsorption of $\mathrm{RhB}$ in the different

\begin{tabular}{|c|c|c|c|c|c|}
\hline \multirow[b]{2}{*}{ Material } & \multirow[b]{2}{*}{$\mathbf{T}\left({ }^{\circ} \mathrm{C}\right)$} & \multicolumn{4}{|c|}{ Thermodynamic parameters } \\
\hline & & $\begin{array}{c}\Delta \mathbf{G}^{\mathbf{0}} \\
\left(\mathrm{kJ} \cdot \mathrm{mol}^{-1}\right)\end{array}$ & $\begin{array}{c}\Delta \mathbf{H}^{\mathbf{0}} \\
\left(\mathrm{kJ} \cdot \mathrm{mol}^{-1}\right)\end{array}$ & $\begin{array}{c}\Delta \mathbf{S}^{\mathbf{0}} \\
\left(\mathrm{J} \cdot \mathrm{mol}^{-1} \cdot \mathrm{K}^{-1}\right)\end{array}$ & $r^{2}$ \\
\hline \multirow{3}{*}{ C_carnauba_ $\mathrm{CaCl}_{2}$} & 25 & -9.069 & & & \\
\hline & 35 & -9.641 & 11.778 & 69.82 & 0.963 \\
\hline & 45 & -10.471 & & & \\
\hline \multirow{3}{*}{ C_carnauba_H $\mathrm{H}_{3} \mathrm{PO}_{4}$} & 25 & -2.229 & & & \\
\hline & 35 & -2.325 & 0.604 & 9.509 & 0.999 \\
\hline & 45 & -2.419 & & & \\
\hline \multirow{3}{*}{ C_macauba_CaCl 2} & 25 & -1.013 & & & \\
\hline & 35 & -2.506 & 28.921 & 100.965 & 0.916 \\
\hline & 45 & -3.011 & & & \\
\hline \multirow{3}{*}{ C_macauba_H $\mathrm{H}_{3} \mathrm{PO}_{4}$} & 25 & -3.098 & & & \\
\hline & 35 & -3.532 & 7.679 & 36.244 & 0.972 \\
\hline & 45 & -3.819 & & & \\
\hline \multirow{3}{*}{ C_pine_nut_shell_CaCl 2} & 25 & -2.449 & & & \\
\hline & 35 & -3.415 & 17.032 & 65.709 & 0.903 \\
\hline & 45 & -3.750 & & & \\
\hline \multirow{3}{*}{ C_pine_nut_shell_ $\mathrm{H}_{3} \mathrm{PO}_{4}$} & 25 & -3.506 & & & \\
\hline & 35 & -4.946 & 38.916 & 142.377 & 0.999 \\
\hline & 45 & -6.353 & & & \\
\hline
\end{tabular}
activated charcoals.

Table 4. Thermodynamic parameters for RhB adsorption for the different activated carbons under study

\subsection{Preliminary assessment of the effect of cellulose content on $\mathrm{RhB}$ removal}

From a comparison of the components for the lignocellulosic materials under study (Table S2) with the textural characteristics of their corresponding activated carbons (Table 1), it can be inferred that the BET surface area and pore volume increase with cellulose content. Cagnon et al. (2009), when using physical activation for the different individual components (cellulose, lignin and hemicellulose), concluded that the activated carbon obtained from cellulose had a higher pore volume $\left(0.32 \mathrm{~cm}^{3} / \mathrm{g}\right)$ than those obtained from lignin $\left(0.30 \mathrm{~cm}^{3} / \mathrm{g}\right)$ and hemicellulose $\left(0.24 \mathrm{~cm}^{3} / \mathrm{g}\right)$. Khezami et al. (2005) also reported a higher mesopore content for the chemical activation (with $\mathrm{KOH})$ of cellulose $\left(0.049 \mathrm{~cm}^{3} / \mathrm{g}\right)$ in comparison to lignin $\left(0.032 \mathrm{~cm}^{3} / \mathrm{g}\right)$ and hemicellulose $(0.048$ $\left.\mathrm{cm}^{3} / \mathrm{g}\right)$.

Consequently, we have conducted a preliminary study aimed at assessing the impact of cellulose content on the RhB removal by adsorption. Pine nut shell has been selected for these tests, provided that its cellulose content is similar to that of macauba endocarp and lower than that of carnauba leaves (so there is more room for improvement). As indicated in the experimental 
section (subsection 2.4), the cellulose content was artificially increased prior to activation with $\mathrm{H}_{3} \mathrm{PO}_{4}$ by adding different amounts of native cellulose ( $0 \mathrm{wt} . \%, 20 \mathrm{wt} . \%$ and $\left.50 \mathrm{wt} . \%\right)$ to the pine nut shell lignocellulosic material. The respective $\mathrm{RhB}$ removal efficiencies are depicted Figure 5. It can be observed that the $\mathrm{RhB}$ removal significantly increases from $78 \%$ for the activated carbon obtained from pure pine nut shell to $97 \%$ when $50 \mathrm{wt} . \%$ of native cellulose was added for the same operational conditions. This improvement, as noted above, would be associated to the higher mesopore ratio for higher cellulose content, which favors RhB adsorption. A detailed study on the suitability of different combinations of native cellulose with lignocellulosic materials for activated charcoals production will be the objective of a further research.
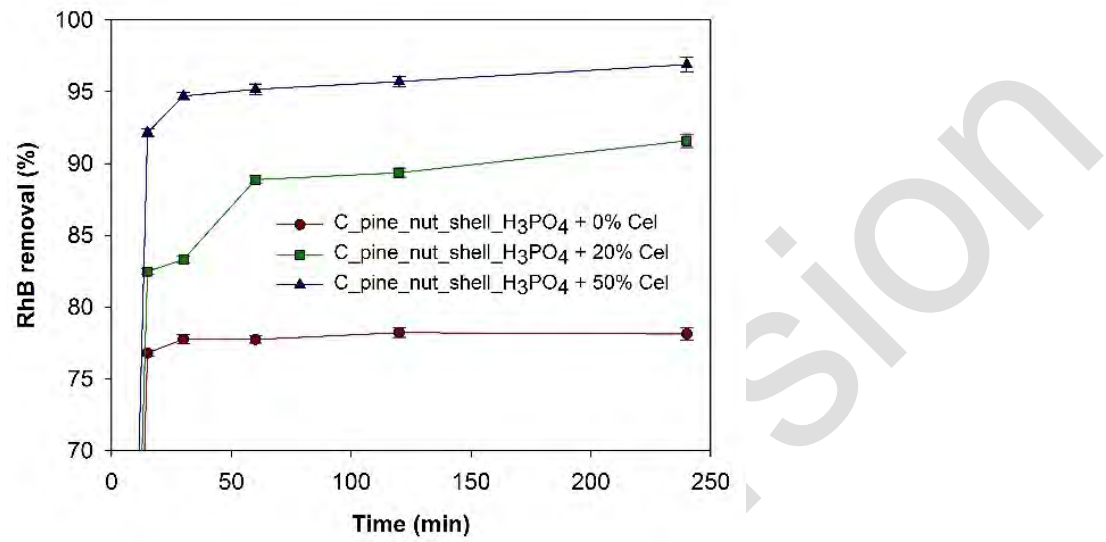

Figure 5. Effect of additional native cellulose dose on $\mathrm{RhB}$ removal using $\mathrm{H}_{3} \mathrm{PO}_{4}$-activated carbons obtained from pine nut shell $\left([\mathrm{RhB}]_{0}=80 \mathrm{mg} / \mathrm{L}, \mathrm{pH}=7\right.$, activated carbon dose $=2 \mathrm{~g} / \mathrm{L}$; temperature $\left.=25^{\circ} \mathrm{C}\right)$.

\section{CONCLUSIONS}

Adsorption studies have been conducted for the different activated carbons obtained from the three selected lignocellulosic waste materials (carnauba palm leaves, macauba endocarp and pine nut shell) to assess their capability to remove Rhodamine $B$ in the aqueous phase. The adsorption process fits a pseudo-second order model, which suggests that the adsorption rate is more dependent on the availability of adsorption sites than on dye concentration, and the equilibrium data fit the Freundlich isotherm model, associated to multilayer adsorption and a heterogeneous energy distribution of the active sites. The adsorptive capacity depends both on the lignocellulosic material used and on the activation procedure, attaining better results for $\mathrm{CaCl}_{2}$ than $\mathrm{H}_{3} \mathrm{PO}_{4}$ activation as a consequence of enhanced mesopore formation. From the thermodynamic parameters $\left(\Delta \mathrm{H}^{0}, \Delta \mathrm{S}^{0}\right.$ and $\left.\Delta \mathrm{G}^{0}\right)$ it can be concluded that the physical adsorption process is endothermic and spontaneous for the all activated carbons, so they can be regarded as promising adsorbents for removal pollutants from aqueous solutions. Finally, the preliminary study on the impact of cellulose content (by adding native cellulose to the precursor) shows that its increase leads to an enhancement of the adsorption properties, associated to improved textural properties.

\section{ACKNOWLEDGEMENTS}

This work was supported by funds from Junta de Castilla y León under project VA036A122. Viviane da Silva would like to thank Universidad de Valladolid for its financial support ("Programa de Formación del Personal Investigador" PhD scholarship).

\section{APPENDIX A. SUPPLEMENTARY DATA}


Supplementary information associated with this article includes thermal analysis, elementary analysis, components analysis, X-ray powder diffraction patterns, vibrational analysis (ATRFTIR), nitrogen absorption/desorption isotherms and pore volume distributions data.

\section{REFERENCES}

Ahmad, F., Daud, W.M.A.W., Ahmad, M.A., Radzi, R., 2012. Cocoa (Theobroma cacao) shell-based activated carbon by $\mathrm{CO}_{2}$ activation in removing of Cationic dye from aqueous solution: Kinetics and equilibrium studies. Chem. Eng. Res. Des. 90, 1480-1490.

Ahmad, R., Kumar, R., 2010. Adsorption studies of hazardous malachite green onto treated ginger waste. J. Environ. Manage. 91, 1032-1038.

Aksu, Z., Dönmez, G., 2003. A comparative study on the biosorption characteristics of some yeasts for Remazol Blue reactive dye. Chemosphere 50, 1075-1083.

ANASI, ASTM, 1977. Standard test methods for lignin in wood D 1106-56. American National Standards Institute (ANSI) and American Society for Testing and Materials (ASTM), Washington DC.

ANSI, ASTM, 1977. Standard test methods for alpha-cellulose in wood D 1103-60. American National Standards Institute (ANSI) and American Society for Testing and Materials (ASTM), Washington DC.

Baccar, R., Bouzid, J., Feki, M., Montiel, A., 2009. Preparation of activated carbon from Tunisian olive-waste cakes and its application for adsorption of heavy metal ions. J. Hazard. Mater. 162, 1522-1529.

Bansode, R., Losso, J., Marshall, W., Rao, R., Portier, R., 2004. Pecan shell-based granular activated carbon for treatment of chemical oxygen demand (COD) in municipal wastewater. Bioresour. Technol. 94, 129-135.

Barrett, E.P., Joyner, L.G., Halenda, P.P., 1951. The Determination of Pore Volume and Area Distributions in Porous Substances. I. Computations from Nitrogen Isotherms. J. Am. Chem. Soc. 73, 373-380.

Bhadusha, N., Ananthabaskaran, T., 2012. Kinetic, Thermodynamic and Equilibrium Studies on Uptake of Rhodamine B onto $\mathrm{ZnCl}_{2}$ Activated Low Cost Carbon. J. Chem. 9, 137-144.

Bhatnagar, A., Kumar, E., Minocha, A.K., Jeon, B.-H., Song, H., Seo, Y.-C., 2009. Removal of Anionic Dyes from Water using Citrus limonum (Lemon) Peel: Equilibrium Studies and Kinetic Modeling. Sep. Sci. Technol. 44, 316-334.

Bouchelta, C., Medjram, M.S., Bertrand, O., Bellat, J.-P., 2008. Preparation and characterization of activated carbon from date stones by physical activation with steam. J. Anal. Appl. Pyrolysis 82, 70-77.

Brasquet, C., Rousseau, B., Estrade-Szwarckopf, H., Le Cloirec, P., 2000. Observation of activated carbon fibres with SEM and AFM correlation with adsorption data in aqueous solution. Carbon $38,407-422$.

Browning, B.L., 1967. Methods of wood chemistry. Interscience Publishers, New York,.

Cagnon, B., Py, X., Guillot, A., Stoeckli, F., Chambat, G., 2009. Contributions of hemicellulose, cellulose and lignin to the mass and the porous properties of chars and steam activated carbons from various lignocellulosic precursors. Bioresour. Technol. 100, 292-298.

Chen, S., Zhang, J., Zhang, C., Yue, Q., Li, Y., Li, C., 2010. Equilibrium and kinetic studies of methyl orange and methyl violet adsorption on activated carbon derived from Phragmites australis. Desalination 252, 149-156.

da Silva Lacerda, V., López-Sotelo, J.B., Correa-Guimarães, A., Hernández-Navarro, S., SánchezBascones, M., Navas-Gracia, L.M., Martín-Ramos, P., Pérez-Lebeña, E., Martín-Gil, J., 2015. A kinetic study on microwave-assisted conversion of cellulose and lignocellulosic waste into hydroxymethylfurfural/furfural. Bioresour. Technol. 180, 88-96.

de Luna, M.D.G., Flores, E.D., Genuino, D.A.D., Futalan, C.M., Wan, M.-W., 2013. Adsorption of Eriochrome Black T (EBT) dye using activated carbon prepared from waste rice hullsOptimization, isotherm and kinetic studies. J. Taiwan Inst. Chem. Eng. 44, 646-653. 
Fernandez, M.E., Nunell, G.V., Bonelli, P.R., Cukierman, A.L., 2014. Activated carbon developed from orange peels: Batch and dynamic competitive adsorption of basic dyes. Ind. Crop. Prod. $62,437-445$.

Forgacs, E., Cserháti, T., Oros, G., 2004. Removal of synthetic dyes from wastewaters: a review. Environ. Int. 30, 953-971.

Freeman, J.J., Gimblett, F.G.R., 1988. Studies of activated charcoal cloth. IV. Influence of phosphate impregnants on the rate of activation in carbon dioxide gas. Carbon 26, 501-505.

Freeman, J.J., Gimblett, F.G.R., Roberts, R.A., Sing, K.S.W., 1988. Studies of activated charcoal cloth. III. Mesopore development induced by phosphate impregnants. Carbon 26, 7-11.

Freundlich, H., 1906. Über die Adsorption in Lösungen. Wilhelm Engelmann, Leipzig.

Gad, H.M.H., El-Sayed, A.A., 2009. Activated carbon from agricultural by-products for the removal of Rhodamine-B from aqueous solution. J. Hazard. Mater. 168, 1070-1081.

Garg, V.K., Kumar, R., Gupta, R., 2004. Removal of malachite green dye from aqueous solution by adsorption using agro-industry waste: a case study of Prosopis cineraria. Dyes Pigments 62, 110.

Guo, Y., Rockstraw, D.A., 2007. Physicochemical properties of carbons prepared from pecan shell by phosphoric acid activation. Bioresour. Technol. 98, 1513-1521.

Hall, K.R., Eagleton, L.C., Acrivos, A., Vermeulen, T., 1966. Pore- and Solid-Diffusion Kinetics in Fixed-Bed Adsorption under Constant-Pattern Conditions. Ind. Eng. Chem. Fundam. 5, 212223.

Hao, W., Björkman, E., Lilliestråle, M., Hedin, N., 2013. Activated carbons prepared from hydrothermally carbonized waste biomass used as adsorbents for $\mathrm{CO}_{2}$. Applied Energy 112, 526-532.

Ho, Y.-S., 1995. Absorption of heavy metals from waste streams by peat. University of Birmingham, Birmingham, United Kingdom.

Hosseini, S., Khan, M.A., Malekbala, M.R., Cheah, W., Choong, T.S., 2011. Carbon coated monolith, a mesoporous material for the removal of methyl orange from aqueous phase: Adsorption and desorption studies. Chem. Eng. J. 171, 1124-1131.

Ioannidou, O., Zabaniotou, A., 2007. Agricultural residues as precursors for activated carbon production-A review. Renew. Sust. Energ. Rev. 11, 1966-2005.

Jagtoyen, M., Derbyshire, F., 1998. Activated carbons from yellow poplar and white oak by $\mathrm{H}_{3} \mathrm{PO}_{4}$ activation. Carbon 36, 1085-1097.

Kadirvelu, K., Karthika, C., Vennilamani, N., Pattabhi, S., 2005. Activated carbon from industrial solid waste as an adsorbent for the removal of Rhodamine-B from aqueous solution: Kinetic and equilibrium studies. Chemosphere 60, 1009-1017.

Karthikeyan, T., Rajgopal, S., Miranda, L.R., 2005. Chromium(VI) adsorption from aqueous solution by Hevea Brasilinesis sawdust activated carbon. J. Hazard. Mater. 124, 192-199.

Khezami, L., Chetouani, A., Taouk, B., Capart, R., 2005. Production and characterisation of activated carbon from wood components in powder: Cellulose, lignin, xylan. Powder Technol. 157, 4856.

Klasson, K.T., Wartelle, L.H., Rodgers III, J.E., Lima, I.M., 2009. Copper (II) adsorption by activated carbons from pecan shells: Effect of oxygen level during activation. Ind. Crop. Prod. 30, 7277.

Kong, J., Yue, Q., Huang, L., Gao, Y., Sun, Y., Gao, B., Li, Q., Wang, Y., 2013. Preparation, characterization and evaluation of adsorptive properties of leather waste based activated carbon via physical and chemical activation. Chem. Eng. J. 221, 62-71.

Lagergren, S., 1898. Zur Theorie der sogenannten Absorption gelöster Stoffe. PA Norstedt \& söner, Stockholm.

Langmuir, I., 1918. The adsorption of gases on plane surface of glass, mica and platinum. J. Am. Chem. Soc. 40, 1361-1403.

Lazaridis, N.K., Asouhidou, D.D., 2003. Kinetics of sorptive removal of chromium(VI) from aqueous solutions by calcined $\mathrm{Mg}-\mathrm{Al}-\mathrm{CO}_{3}$ hydrotalcite. Water Res. 37, 2875-2882. 
Lin, L., Zhai, S.-R., Xiao, Z.-Y., Song, Y., An, Q.-D., Song, X.-W., 2013. Dye adsorption of mesoporous activated carbons produced from $\mathrm{NaOH}$-pretreated rice husks. Bioresour. Technol. $136,437-443$.

Lo, S.-F., Wang, S.-Y., Tsai, M.-J., Lin, L.-D., 2012. Adsorption capacity and removal efficiency of heavy metal ions by Moso and Ma bamboo activated carbons. Chem. Eng. Res. Des. 90, 13971406.

Metcalf, Eddy, 2003. Wastewater engineering: Treatment and reuse, Nueva York.

Namasivayam, C., Radhika, R., Suba, S., 2001. Uptake of dyes by a promising locally available agricultural solid waste: coir pith. Waste Manage. (Oxford) 21, 381-387.

Ng, C., Marshall, W.E., Rao, R.M., Bansode, R.R., Losso, J.N., 2003. Activated carbon from pecan shell: process description and economic analysis. Ind. Crop. Prod. 17, 209-217.

Parab, H., Sudersanan, M., Shenoy, N., Pathare, T., Vaze, B., 2009. Use of Agro-Industrial Wastes for Removal of Basic Dyes from Aqueous Solutions. Clean 37, 963-969.

Paraskeva, P., Kalderis, D., Diamadopoulos, E., 2008. Production of activated carbon from agricultural by-products. J. Chem. Technol. Biotechnol. 83, 581-592.

Pastor-Villegas, J., Pastor-Valle, J.F., Rodríguez, J.M.M., García, M.G., 2006. Study of commercial wood charcoals for the preparation of carbon adsorbents. J. Anal. Appl. Pyrolysis 76, 103-108.

Peláez-Cid, A.A., Teutli-León, M.M., 2012. Lignocellulosic precursors used in the elaboration of activated carbon, in: Petriciolet, V.H.M.a.A.B. (Ed.), Lignocellulosic Precursors Used in the Synthesis of Activated Carbon-Characterization Techniques and Applications in the Wastewater Treatment.

Phan, N.H., Rio, S., Faur, C., Le Coq, L., Le Cloirec, P., Nguyen, T.H., 2006. Production of fibrous activated carbons from natural cellulose (jute, coconut) fibers for water treatment applications. Carbon 44, 2569-2577.

Santhi, T., Prasad, A.L., Manonmani, S., 2014. A comparative study of microwave and chemically treated Acacia nilotica leaf as an eco friendly adsorbent for the removal of rhodamine B dye from aqueous solution. Arabian J. Chem. 7, 494-503.

Sing, K.S.W., 1985. Reporting physisorption data for gas/solid systems with special reference to the determination of surface area and porosity (Recommendations 1984), Pure Appl. Chem., p. 603.

Talebnia, F., Karakashev, D., Angelidaki, I., 2010. Production of bioethanol from wheat straw: An overview on pretreatment, hydrolysis and fermentation. Bioresour. Technol. 101, 4744-4753.

Wang, L., Zhang, J., Zhao, R., Li, C., Li, Y., Zhang, C., 2010. Adsorption of basic dyes on activated carbon prepared from Polygonum orientale Linn: Equilibrium, kinetic and thermodynamic studies. Desalination 254, 68-74.

Wang, S., Zhu, Z.H., 2007. Effects of acidic treatment of activated carbons on dye adsorption. Dyes Pigments 75, 306-314.

Zaini, M.A.A., Amano, Y., Machida, M., 2010. Adsorption of heavy metals onto activated carbons derived from polyacrylonitrile fiber. J. Hazard. Mater. 180, 552-560.

Zhou, A., Ma, X., Song, C., 2009. Effects of oxidative modification of carbon surface on the adsorption of sulfur compounds in diesel fuel. Appl. Catal., B 87, 190-199.

Zuo, S., Yang, J., Liu, J., Cai, X., 2009. Significance of the carbonization of volatile pyrolytic products on the properties of activated carbons from phosphoric acid activation of lignocellulosic material. Fuel Process. Technol. 90, 994-1001. 